\title{
Fluxes of microbes, organic aerosols, dust, sea-salt Na ions, non-sea-salt Ca ions, and methanesulfonate onto Greenland and Antarctic ice
}

\author{
P. B. Price, R. A. Rohde, and R. C. Bay \\ Physics Department, University of California, Berkeley, CA 94720, USA \\ Received: 30 September 2008 - Published in Biogeosciences Discuss.: 3 December 2008 \\ Revised: 3 February 2009 - Accepted: 5 March 2009 - Published: 27 March 2009
}

\begin{abstract}
Using a spectrofluorimeter with 224-nm laser excitation and six emission bands from 300 to $420 \mathrm{~nm}$ to measure fluorescence intensities at $0.3-\mathrm{mm}$ depth intervals in ice cores, we report results of the first comparative study of concentrations of microbial cells (using the spectrum of proteinbound tryptophan (Trp) as a proxy) and of aerosols with autofluorescence spectra different from Trp (denoted "nonTrp") as a function of depth in ice cores from West Antarctica (WAIS Divide and Siple Dome) and Greenland (GISP2). The ratio of fluxes of microbial cells onto West Antarctic (WAIS Divide) versus Greenland sites is $0.13 \pm 0.06$; the ratio of non-Trp aerosols onto WAIS Divide versus Greenland sites is $0.16 \pm 0.08$; and the ratio of non-sea-salt $\mathrm{Ca}^{2+}$ ions (a proxy for dust grains) onto WAIS Divide versus Greenland sites is $0.06 \pm 0.03$. All of these are roughly comparable to the ratio of fluxes of dust onto Antarctic versus Greenland sites $(0.08 \pm 0.05)$. By contrast to those values, which are considerably lower than unity, the ratio of fluxes of methanesulfonate (MSA) onto Antarctic versus Greenland sites is $1.9 \pm 0.4$ and the ratio of sea-salt $\mathrm{Na}^{2+}$ ions onto WAIS Divide versus Greenland sites is $3.0 \pm 2$. These ratios are more than an order of magnitude higher than those in the first grouping. We infer that the correlation of microbes and nonTrp aerosols with non-sea-salt $\mathrm{Ca}$ and dust suggests a largely terrestrial rather than marine origin. The lower fluxes of microbes, non-Trp aerosols, non-sea-salt $\mathrm{Ca}$ and dust onto WAIS Divide ice than onto Greenland ice may be due to the smaller areas of their source regions and less favorable wind patterns for transport onto Antarctic ice than onto Greenland ice. The correlated higher relative fluxes of MSA and marine $\mathrm{Na}$ onto Antarctic versus Greenland ice is consistent with the
\end{abstract}

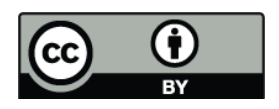

Correspondence to: P. B. Price (bprice@ berkeley.edu) view that both originate largely on or around sea ice, with the Antarctic sea ice being far more extensive than that around Greenland.

\section{Introduction}

In recent years biologists have determined concentrations and taxa of microorganisms at a few depths in polar ice (Miteva et al., 2004; Priscu and Christner, 2004; Price, 2007) and permafrost (Gilichinsky, 2002). Due to the labor involved in extracting microbes from ice and analyzing them under sterile conditions, no systematic study has heretofore been made of the concentrations of microbes and their rates of deposition onto the two polar caps as a function of depth. By contrast, because of their value as monitors of Earth's climate, atmospheric gases such as $\mathrm{CH}_{4}, \mathrm{~N}_{2} \mathrm{O},{ }^{18} \mathrm{O}$, and $\mathrm{CO}_{2}$ (Chappellaz et al., 1997; Sowers et al., 2003; Grootes et al., 1993; Bender et al., 1994; Petit et al., 1999), methanesulfonate (MSA) (Legrand et al., 1991; Saltzman et al., 1997), mineral dust (De Angelis et al., 1997; Delmonte et al., 2004) and major elements have been thoroughly studied as a function of depth in a number of ice cores from sites in Antarctica and Greenland.

We have recently developed and employed a 224-nm laser scanning spectrofluorimeter to detect and map concentrations of microbes and non-microbial aerosols at depth intervals of $0.3 \mathrm{~mm}$ throughout long depth intervals in ice cores. Among our recent results, we showed that some microbial cells are located in liquid veins in the ice, that some metabolizing cells are located in the ice lattice rather than in veins, and that at some depths the microbial concentration is so high that products of their ongoing metabolism give rise to localized excesses in $\mathrm{N}_{2} \mathrm{O}$ that interfere with the role of $\mathrm{N}_{2} \mathrm{O}$ as a

Published by Copernicus Publications on behalf of the European Geosciences Union. 
Table 1. Relative Concentrations and Fluxes of Microbial Cells, non-Trp Aerosols, sea-salt $\mathrm{Na}^{+}$, non-sea-salt Ca ${ }^{2+}$, Mineral Dust, and MSA in Antarctic/Greenland Ice.

\begin{tabular}{|c|c|c|c|}
\hline Part 1. Fluorimetry: microbes and non-Trp aerosols at $1.5 \mathrm{ka}$ & Concentration ratio & Accumulation ratio & Flux ratio \\
\hline $\begin{array}{l}(\text { microbes in WAIS ice*) } \div \\
(\text { microbes in GISP2 ice*) }\end{array}$ & $0.19 \pm 0.1$ cells $/$ cell & $16 / 23$ & $0.13 \pm 0.06$ \\
\hline $\begin{array}{l}(\text { non-Trp aerosols in WAIS ice*) } \div \\
(\text { non-Trp aerosols in GISP2 ice*) }\end{array}$ & $0.24 \pm 0.12$ particles/particle & $16 / 23$ & $0.16 \pm 0.08$ \\
\hline \multicolumn{4}{|l|}{ Part 2. Mineral dust grains } \\
\hline Dome $\mathrm{C}^{\mathrm{b}} / \mathrm{NGRIP} \mathrm{a}^{\mathrm{a}}$ (Holocene, 3 to $5 \mathrm{ka}$ ) & $0.26 \pm 0.04 \mathrm{~g} / \mathrm{g}$ & $3.05 / 24$ & 0.033 \\
\hline EDML $^{\mathrm{c}} /$ NGRIP $^{\mathrm{a}}$ (Holocene, 3 to $5 \mathrm{ka}$ ) & $0.54 \pm 0.1$ & $6.4 / 24$ & 0.14 \\
\hline Vostok $^{\mathrm{b}} /$ NGRIP (Holocene, 3 to $5 \mathrm{ka}$ ) & $0.43 \pm 0.04$ & $2.2 / 24$ & 0.039 \\
\hline Dome $\mathrm{C}^{\mathrm{b}} / \mathrm{NGRIP}^{\mathrm{a}}$ (LGM, 20 to $\left.23 \mathrm{ka}\right)$ & $0.23 \pm 0.08$ & $1.4 / 6.5$ & 0.05 \\
\hline $\mathrm{EDML}^{\mathrm{c}} / \mathrm{NGRIP}^{\mathrm{a}}$ (LGM, 20 to $23 \mathrm{ka}$ ) & $0.33 \pm 0.1$ & $3 / 7$ & 0.14 \\
\hline Vostok $^{\mathrm{b}} / \mathrm{NGRIP}^{\mathrm{a}}$ (LGM, 20 to $\left.23 \mathrm{ka}\right)$ & $0.33 \pm 0.1$ & $1.2 / 7$ & 0.057 \\
\hline Average Antarctic dust/Greenland dust & $0.35 \pm 0.11$ & - & $0.08 \pm 0.05$ \\
\hline \multicolumn{4}{|l|}{ Part 3. Non-sea-salt $\mathrm{Ca}^{2+}$ ions } \\
\hline Dome $\mathrm{C}^{\mathrm{i}} / \mathrm{GISP} 2^{\mathrm{k}}$ (Holocene, 3 to $5 \mathrm{ka}$ ) & $1 / 6.48 \mathrm{~g} / \mathrm{g}$ & $3.05 / 23$ & $0.020 \pm 0.01$ \\
\hline Dome $\mathrm{C}^{i} / \mathrm{GISP} 2^{\mathrm{k}}$ (LGM, 20 to $\left.23 \mathrm{ka}\right)$ & $40 / 179$ & $1.4 / 7$ & $0.045 \pm 0.02$ \\
\hline WAIS Divide $^{j}$ /GISP2 $^{\mathrm{k}}$ (Holocene, $0.5 \mathrm{ka}$ ) & $0.83 / 6.48$ & $16 / 23$ & $0.09 \pm 0.07$ \\
\hline Siple $^{1} /$ GISP2k ${ }^{k}$ Holocene, 0.5 ka) & $1.3 / 6.48$ & $11 / 23$ & $0.1 \pm 0.05$ \\
\hline $\mathrm{Siple}^{1 /} \mathrm{GISP}^{\mathrm{k}}$ (LGM, 20 to $\left.23 \mathrm{ka}\right)$ & $12 / 179$ & $4 / 7$ & 0.038 \\
\hline Average Antarctic $\mathrm{Ca} / \mathrm{Greenland} \mathrm{Ca}$ & $0.15 \pm 0.08$ & - & $0.06 \pm 0.03$ \\
\hline \multicolumn{4}{|l|}{ Part 4. Sea-salt $\mathrm{Na}^{+}$ions } \\
\hline Dome $\mathrm{C}^{\mathrm{i}} / \mathrm{GISP} 2^{k}$ (Holocene, 3 to $\left.5 \mathrm{ka}\right)$ & $20 / 4.5 \mathrm{~g} / \mathrm{g}$ & $3.05 / 23$ & $0.59 \pm 0.3$ \\
\hline Dome $\mathrm{C}^{\mathrm{i}} / \mathrm{GISP} 2^{k}(\mathrm{LGM}, 20$ to $23 \mathrm{ka})$ & $80 / 52$ & $1.4 / 7$ & $0.31 \pm 0.15$ \\
\hline WAIS Divide $/ \mathrm{G} / \mathrm{SSP} 2^{\mathrm{k}}$ (Holocene, $0.5 \mathrm{ka}$ ) & $19.6 / 4.5$ & $16 / 23$ & $3.13 \pm 1.6$ \\
\hline Siple $^{1} /$ GISP2 $^{\mathrm{k}}$ (Holocene, 3 to $5 \mathrm{ka}$ ) & $93 / 4.5$ & $11 / 23$ & 9.9 \\
\hline Siple $^{1 /}$ GISP2 $^{\mathrm{k}}$ (LGM, 20 to $\left.23 \mathrm{ka}\right)$ & $92 / 52$ & $4 / 7$ & 1.0 \\
\hline Average Antarctic $\mathrm{Na} /$ Greenland $\mathrm{Na}$ & $6.6 \pm 3$ & - & $3.0 \pm 2.0$ \\
\hline \multicolumn{4}{|l|}{ Part 5. Methanesulfonate (MSA) } \\
\hline Siple $^{\mathrm{d}} / \mathrm{GISP}^{\mathrm{e}}$ (Holocene) & $4 \pm 1 \mathrm{~g} / \mathrm{g}$ & $11 / 23$ & $1.9 \pm 0.5$ \\
\hline Siple $^{\mathrm{d}} / \mathrm{GISP}^{\mathrm{e}}$ (LGM) & $4.6 \pm 0.7$ & $4 / 7$ & $2.6 \pm 0.45$ \\
\hline Vostok ${ }^{\mathrm{f}} /$ GRIPg (LGM) & $9 \pm 1.5$ & $1.2 / 7$ & $1.5 \pm 0.25$ \\
\hline Vostok $^{\mathrm{f}} / \mathrm{NGRIP}^{\mathrm{h}}$ (LGM) & $8 \pm 1.6$ & $1.2 / 7$ & $1.4 \pm 0.3$ \\
\hline Average Antarctic MSA/Greenland MSA & $6.4 \pm 2.8$ & - & $1.9 \pm 0.4$ \\
\hline
\end{tabular}

* This work. ${ }^{\mathrm{a}}$ Ruth et al. (2003); ${ }^{\mathrm{b}}$ Delmonte et al. (2004); ${ }^{\mathrm{c}}$ Ruth et al. (2008); ${ }^{\mathrm{d}}$ Saltzman et al. (2006); ${ }^{\mathrm{e}}$ Saltzman et al. (1997); ${ }^{\mathrm{f}}$ M. Legrand et al. (1991); ${ }^{\mathrm{g}}$ Legrand et al. (1997); ${ }^{\mathrm{h}}$ Jonsell et al. (2007); ${ }^{\mathrm{i}}$ Wolff et al. (2006) and Röthlisberger et al. (2003); ${ }^{\mathrm{j}}$ McConnell (2008, private communication); ${ }^{k}$ Mayewski et al. (1997); ${ }^{l}$ Mayewski and Kreutz (unpublished, 2008).

climate proxy (Rohde and Price, 2007; Rohde et al., 2008). We also showed that microbes and non-Trp aerosols are deposited in discrete bursts with peak values that fluctuate on seasonal to decadal scales. Large fluctuations on depth scales from millimetric to metric are common, which has led us to suggest that scanning fluorimetry may provide both shortterm (meteorological) and long-term (climatological) information on abrupt changes of wind speed or direction over the last $10^{5}$ to $10^{6}$ years for which ice core records exist.
Figures 1 to 3 summarize results of scanning fluorimetric measurements of concentrations of microbes and non-Trp aerosols in Greenland and Antarctic ice cores we carried out at the National Ice Core Laboratory. Table 1 compares our fluorimetric results with data of others on dust grains, seasalt $\mathrm{Na}^{+}$, non-sea-salt $\mathrm{Ca}^{2+}$, and MSA, from which we will draw conclusions about likely sources. 

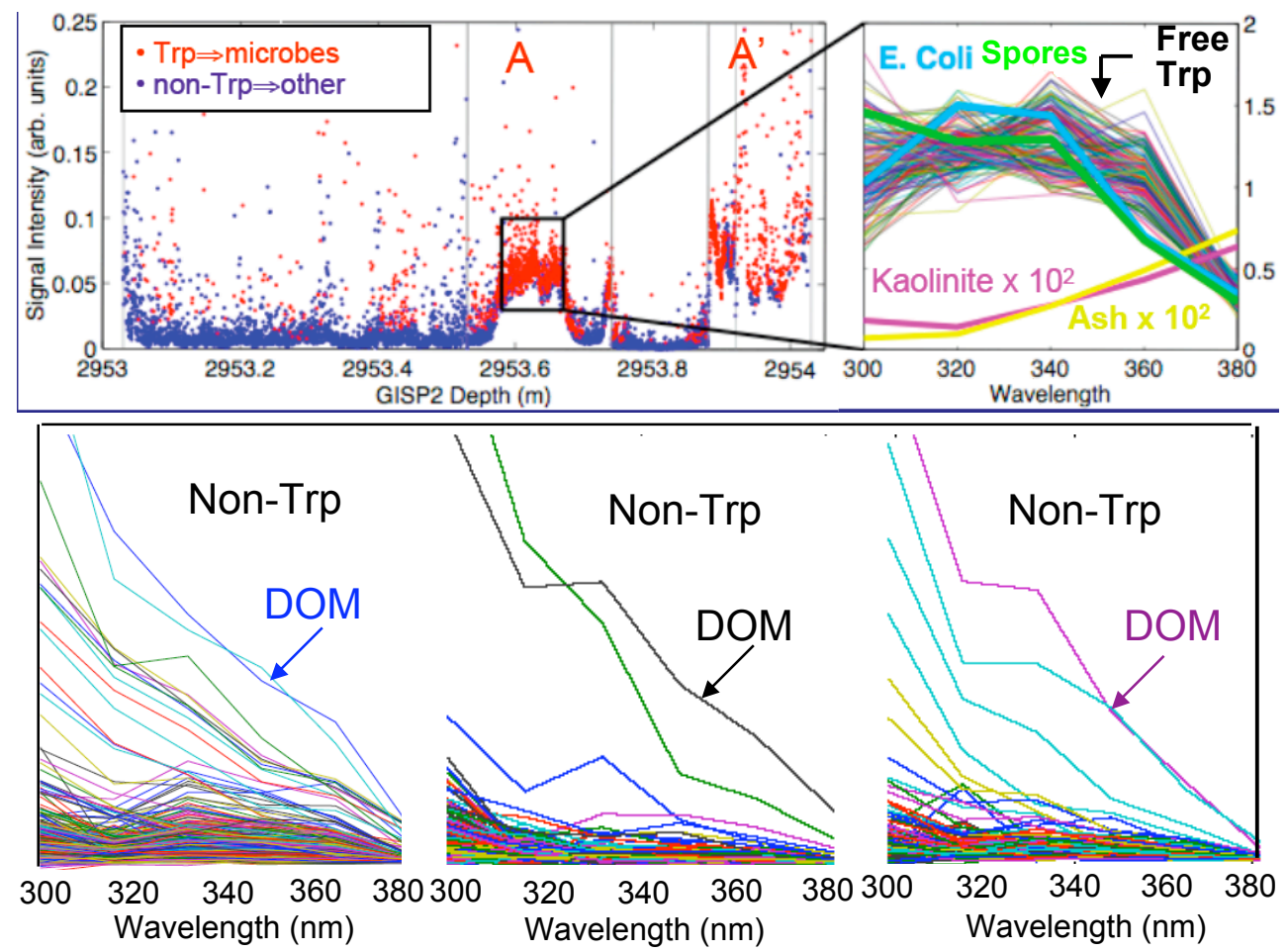

Fig. 1. Upper panels: calibration of spectrofluorimeter to microbes. (Left side) intensity of fluorescence along a 1-m section of GISP2 ice. Points in red indicate protein fluorescence; points in blue have spectra inconsistent with proteins. (Right side) Spectra for measurements in the boxed region compared with spectra for lab specimens for bacteria and minerals. Arrow indicates wavelength for which free Trp would show a maximum. Curves in lower three panels show examples of non-Trp spectra.

\section{Materials and methods}

Full names of the ice cores referred to in the text and in Table 1 are:

\section{Deep cores in West Antarctica:}

WAIS Divide: West Antarctic Ice Sheet Divide, a US drilling project, now in progress, that is expected to produce a core $\sim 3500 \mathrm{~m}$ deep to bedrock in 2011.

Siple Dome: previous US Antarctic drilling project that produced a $\sim 1004$-m core to bedrock.

\section{Deep cores in East Antarctica:}

Vostok Station: Russia's drilling project that produced a 3700-m core extending almost down to subglacial Lake Vostok.

Dome C: EPICA (European Project for Ice Coring in Antarctica) core at Dome C.

EDML: EPICA Dronning Maud Land core.

\section{Deep cores in Central Greenland:}

GRIP: Greenland Ice Core Project, a European borehole extending down to $\sim 3029 \mathrm{~m}$ at Summit.

GISP2: second Greenland Ice Sheet Project, a US borehole to bedrock at $3044 \mathrm{~m}, 30 \mathrm{~km}$ from the GRIP borehole.

NGRIP: Northern Greenland Ice Core Project, a European borehole $\sim 320 \mathrm{~km}$ north of GRIP.

We have recently discussed our method of determining concentrations of microbes and non-microbial aerosols based on the spectral shapes in six channels of emission wavelength resulting from fluorescence excited by our 224-nm laser (Rohde and Price, 2007; Rohde et al., 2008). We calibrated the instrument by relating the intensity of protein-bound tryptophan (Trp) autofluorescence in microbial cells to direct counts of stained cells in the GISP2 ice core from Greenland (Tung et al., 2005).

We measured fluorescence spectra at $-25^{\circ} \mathrm{C}$ in ice cores in the National Ice Core Laboratory in Denver. The cores were from boreholes in three locations. From the GISP2 site we scanned 76 ice cores at selected depths from 286 to $3042 \mathrm{~m}$. From West Antarctica we scanned portions of 20 cores from depths 70 to $295 \mathrm{~m}$ at the WAIS Divide site and portions of 16 cores from depths 58 to $1003 \mathrm{~m}$ at the Siple Dome site. In order to ensure consistent performance of the calibrated 
fluorimeter, we scanned all of the cores, typically at $0.3 \mathrm{~mm}$ intervals throughout $1-\mathrm{m}$ core lengths, in the same run.

For the $\sim 3 \times 10^{5}$ depths where we measured fluorescence, we divided the spectra into two categories, denoted by red points and blue points, as shown in Fig. 1. We attributed the red category, with emission peaked at 320 to $340 \mathrm{~nm}$ and monotonically decreasing at longer wavelengths, to proteinbound Trp in microbial cells (Rohde and Price, 2007). The spectra from the red points within the rectangle in the upper left of Fig. 1 are shown on the upper right. Essentially all of those spectra are consistent with the spectral shape of protein-bound Trp. See Rohde et al. (2008) for experimental details, including a discussion of how we used ground-truth measurements of cells to relate cell size and concentration to fluorescence intensity. The curves in the upper right panel are color-coded to indicate the different spectral shapes for E. coli cells, bacillus spores, kaolinite clay grains, and volcanic ash.

We attributed the blue points, with emission spectra peaked at wavelengths other than 320 to $340 \mathrm{~nm}$, to nonmicrobial (non-Trp) aerosols, which included marine and soil-derived humics and fulvics, as well as the few mineral grains with fluorescent intensity above background. Rohde et al. (2008) showed that, of the non-Trp particles, the few events with very strong fluorescence spectra that monotonically decreased with emission wavelength were a good match to the spectra of some of the dissolved organic matter (DOM) that had been transported from near-surface ocean water (Mopper and Schultz, 1993) into the atmosphere. Several examples of such spectra are labeled (DOM) in Fig. 1. The majority of the blue points had spectra with weaker, nonmonotonically decreasing intensity, similar in shapes to those characterized by Pan et al. (2007), who measured fluorescence spectra of single organic aerosol particles collected in the troposphere above Connecticut and New Mexico.

A powerful advantage of the 224-nm laser for microbial studies is that most mineral grains excited at that wavelength fluoresce extremely weakly and have spectral shapes peaked at wavelengths longer than $380 \mathrm{~nm}$, distinctly different from the spectrum from Trp.

Miteva and Brenchley (2005) and Tung et al. (2005, 2006) found from Scanning Electron Microscopy that bacteria in GISP2 ice have sizes typically 0.2 to $0.5 \mu \mathrm{m}$, and Priscu (private communication, 2007) found from flow cytometry that, in the WAIS Divide ice core, both biotic particles (those containing DNA that stains with a dye such as Syto 60) and abiotic particles have sizes peaked at $0.3 \mu \mathrm{m}$. By contrast, studies of aerosol fluorescence spectra have generally been made on concentrates of atmospheric and marine aerosols (Yamashita and Tanoue, 2003; Coble, 1996) or on single aerosol particles with supermicron sizes (Pan et al., 2007) and thus may not have been representative of the majority of aerosol particles trapped in glacial ice.

Some of our Trp spectra may have been due to free Trp or to proteins not associated with live cells. Free Trp has a

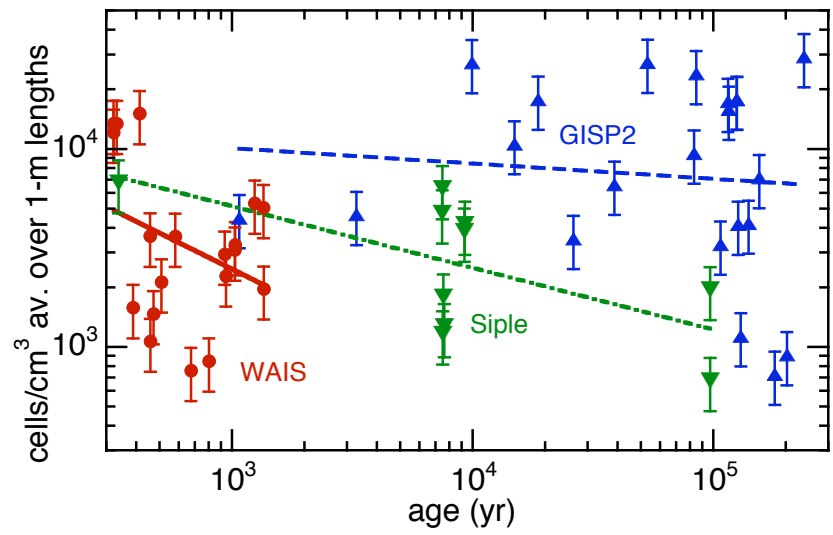

Fig. 2. Microbial cell concentrations inferred from Trp fluorescence in ice cores from WAIS, Siple, and GISP2. Symbols are average values in individual core sections up to $1 \mathrm{~m}$ in length. Microbial cells from some depths in GISP2 ice with ages $>1.1 \times 10^{5} \mathrm{yr}$ may have originated in basal ice and been transported upward by turbulent flow. Lines are power law fits with points for a given core given equal weight. Because GISP2 ice with ages $>1.1 \times 10^{5} \mathrm{yr}$ are uncertain, those data are excluded from the fits.

rather sharp emission peak at $353 \mathrm{~nm}$, whereas the emission peak for protein-bound $\operatorname{Trp}$ is $\sim 330 \mathrm{~nm}$, the downshift being the result of binding into proteins. About $10 \%$ of the spectra we characterized as Trp-like had a peak more consistent with that of free than of bound Trp. Based on ground-truth calibrations in which we compared counts of particles with Trp-like spectra with direct counts of stained cells at various depths in the GISP2 ice (Tung et al., 2005), we conclude that the great majority of the points with Trp-like spectra were due to proteins in microbial cells. Using a live/dead stain for their direct counts of cells, Miteva et al. (2006) found that the fraction alive in GISP2 ice (i.e., with uncompromised membranes) at various depths ranged from $\sim 2.5 \%$ to $\sim 80 \%$. Even those that failed the live/dead test were celllike in shape, from which we surmise that they would have showed Trp-like spectra.

Snow accumulation rates at various polar sites vary in a complex way with glacial stage and with abrupt climate change. In Table 1 we used the most authoritative values in the literature. See Cuffey and Clow (1997) for a discussion of how accumulation rates are determined from data on annual layer thicknesses.

\section{Results and discussion}

Figures 2 and 3 display our data, averaged over core lengths of up to $\sim 1 \mathrm{~m}$ to avoid clutter. The lines are power law fits to cell counts (from spectra of protein-bound Trp) and non-Trp fluorescence counts for WAIS, Siple, and GISP2 ice cores. The abscissae show ages converted from sample depths using established age vs. depth relations. Systematic errors, 


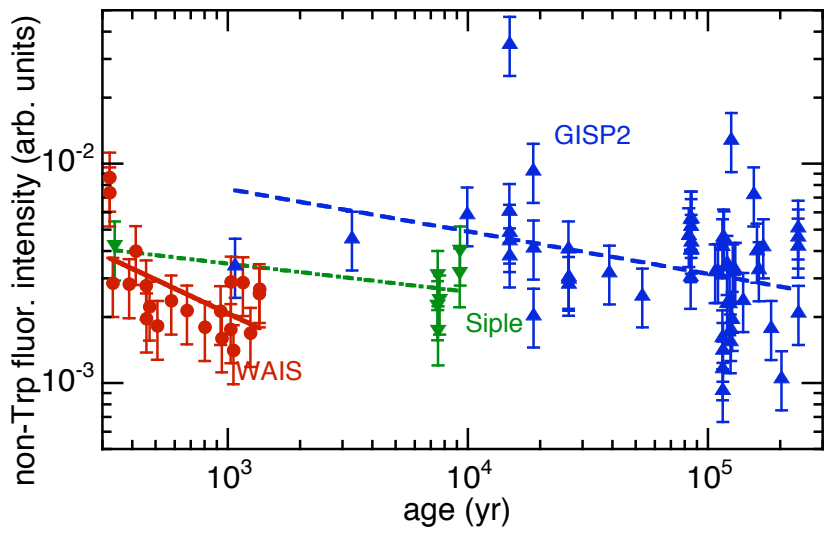

Fig. 3. Concentrations of aerosols (dominantly organic) from nonTrp fluorescence spectra (same symbols and lines as in Fig. 2). Symbols are average values in 1-meter depth intervals. Non-Trp particles from some depths in GISP2 ice with ages $>1.1 \times 10^{5} \mathrm{yr}$ may have originated in basal ice and been transported upward by turbulent flow. Lines are power law fits with points for a given core given equal weight; because GISP2 ice with ages $>1.1 \times 10^{5} \mathrm{yr}$ are uncertain, those data are excluded from the fits.

taken as $\pm 30 \%$ for each point, dominate over statistical errors. They are mainly due to uncertainty in the distribution of cell sizes with depth and to the uncertain fraction of the Trp-like spectra that might be due to proteins not in cells. The large scatter of fluorescence intensities with depth exemplifies the stochastic nature of the deposition of microbes and non-Trp aerosols onto the ice. The smaller the volume of illuminated ice from which the induced fluorescence was received by the fluorimeter, the larger the fluctuations. For the present work the volume sampled by a single laser pulse was a cylinder $\sim 200 \mu \mathrm{m}$ in diameter and $\sim 0.5 \mathrm{~cm}$ in depth. In an ongoing unpublished study with a new fluorimeter designed by Rohde, the volume sampled is more than $10^{2}$ times greater ( 1 to $2 \mathrm{~mm}$ beam diameter, depth 1 to $2 \mathrm{~cm}$ ), as a consequence of which the fluctuations in microbial and non-Trp concentrations are much smaller.

Table 1 compares our measurements of relative concentrations and fluxes of microbial cells and non-Trp aerosols with relative concentrations and fluxes of mineral dust, nonsea-salt $\mathrm{Ca}^{2+}$ ions, sea-salt $\mathrm{Na}^{+}$ions, and MSA in various ice cores. In column 2 the ratios of concentrations (cells per cell, particles per particle, or $\mathrm{g}$ per $\mathrm{g}$ ) are shown for the East and West Antarctic and Greenland locations in column 1. The ratios of fluxes into the ice (column 4) were obtained by multiplying the concentration ratios by the ratios of ice accumulation rates (column 3). In Part 1 of the table, our data on microbes in ice at the West Antarctic sites (WAIS and Siple) relative to those at the GISP2 site are based on values of the averages in Fig. 2 taken at $\sim 1.5 \mathrm{ka}$ (1500 years) before present where data from the sites overlap. The data for non-Trp aerosols at $\sim 1.5 \mathrm{ka}$ are obtained from Fig. 3. Part 2 gives ratios we calculated for mineral dust in ice cores from

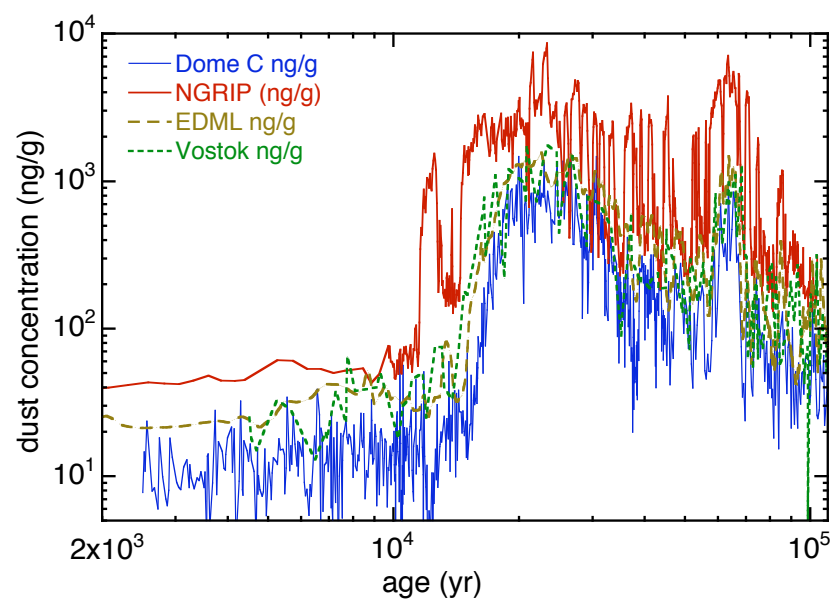

Fig. 4. Concentration of mineral dust at Greenland and Antarctic sites. See Table 1 for references.

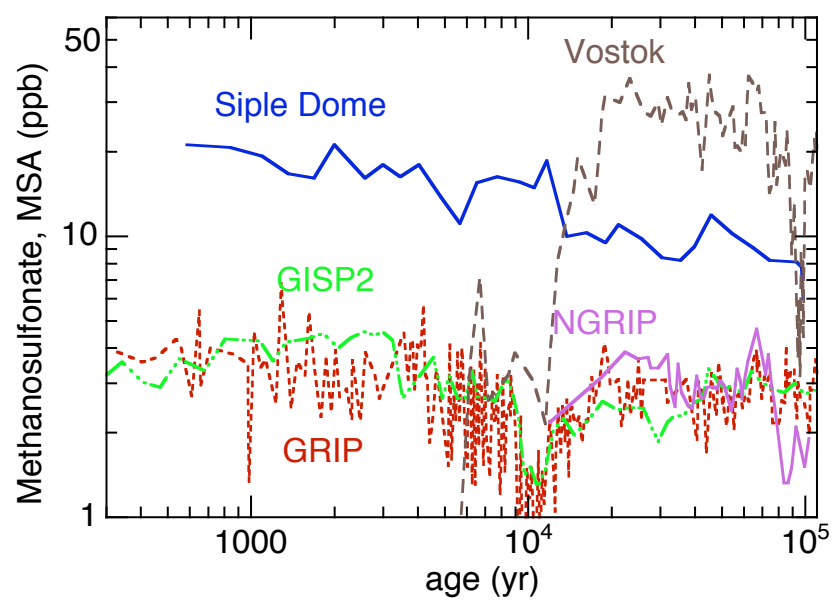

Fig. 5. Concentration of MSA at Greenland and Antarctic sites. See Table 1 for references.

Antarctic and Greenland sites for part of the Holocene period ( 3 to $5 \mathrm{ka}$ ) and for the LGM (Last Glacial Maximum, 20 to $23 \mathrm{ka}$ ), using the data in Fig. 4 . Parts 3 and 4 give ratios we obtained for non-sea-salt $\mathrm{Ca}^{2+}$ ions and sea-salt $\mathrm{Na}^{+}$ ions from Antarctic and Greenland sites, using data from the references at the bottom of Table 1. Part 5 gives ratios for MSA in ice cores from Antarctic and Greenland sites, using the data in Fig. 5.

It is interesting to compare the relative contributions by mass of microbial cells and of dust grains to the Antarctic and Greenland ice. The average mass per microbial cell in glacial ice is $\sim 38 \mathrm{fg}$ (Tung et al., 2005), whereas the average mass per micron-size dust grain in glacial ice is $\sim 300$ times greater. From the data in Table 1, we estimate that microbial cells in Greenland and Antarctic ice contribute only $\sim 1 \%$ as much mass as do dust grains. 
Table 1, along with Figs. 2 and 3, provides an overview of results of our use of scanning spectrofluorimetry to infer microbial concentrations and non-Trp aerosols in glacial ice. In column 4 we call attention to the fact that fluxes of microbes, non-Trp aerosols, and mineral dust onto Antarctic ice are only $\sim 8 \%$ to $\sim 16 \%$ as great as onto Greenland ice. The small values of those flux ratios suggest that Antarctic sources have a smaller source area and/or less direct flight paths than Greenland sources. Li et al. (2008) concluded from modeling that Patagonia (South America) and Australia are the main sources of the dust deposited in Antarctica but that they differ zonally, with each one dominating half of a hemisphere along $120^{\circ} \mathrm{E}-60^{\circ} \mathrm{W}$ : the half comprising the Atlantic and Indian Oceans in the case of Patagonian dust and the Pacific half in the case of the Australian dust. Another subtlety is that there may have been a shift in the main source of the dust between interglacial and glacial periods (RevelRolland et al., 2006). For Greenland ice, the Taklimakan and Gobi deserts in China are the dominant sources of dust for both glacial and interglacial periods (Bory et al., 2003).

From the data in Table 1, we would like to infer the sources of the microbes deposited in the Antarctic and Greenland ice. Since dust data in $\mathrm{g} / \mathrm{g}$ are not available for West Antarctic sites and microbial data at frequent depth intervals are not available for East Antarctic sites, we are not able to compare fluxes of dust and microbes at the same Antarctic sites. Instead, we follow the traditional practice of using concentrations of sea-salt $\mathrm{Na}^{+}$and non-sea-salt $\mathrm{Ca}^{2+}$ as proxies for marine and terrestrial sources of particles transported from ocean and land surfaces, respectively. In Part 3 of Table 1 we see that the ratio of fluxes of marine $\mathrm{Ca}^{2+}$ ions at Antarctic sites relative to Greenland sites is much less than unity, averaging $0.06 \pm 0.03$, whereas in Part 4 the average flux ratio for sea-salt $\mathrm{Na}$ ions is $3.0 \pm 2.0$, more than an order of magnitude greater. We infer from the low Antarctic/Greenland flux ratios of the microbes and non-Trp aerosols and their good correlation with the dust and low Ca flux ratios that the microbes and non-Trp aerosols originated predominantly in terrestrial desert and soil rather than in oceans. Thus, most of the microbes and aerosols in Greenland ice probably originated in the Taklimakan and Gobi deserts and most of those in Antarctic ice probably came from Patagonia and Australia. In due course, DNA analysis may be able to determine the origins of at least some of the microbes.

The average flux ratio for sea-salt $\mathrm{Na}$ (Part 4) is $3.0 \pm 2.0$ and the ratio for MSA is $1.9 \pm 0.4$ (Part 5), both of which have much higher values than the ratios for microbes, nonTrp aerosols, and dust (Parts 1 to 3). According to Wolff (2006), the best interpretation of the main source of sea salt is not open ocean; instead, it is sea ice surfaces, either in the form of frost flower crystals, brine slush, or a brine-soaked snowpack.

For MSA the source is also thought to be sea ice, but more likely the margins. MSA is one of the atmospheric oxidation products of dimethyl sulfide, a metabolic byproduct of dimethylsulfoniopropionate (DMSP), produced primarily by haptophytes (a phylum of algae), as shown by Keller et al. (1989). Prymnesiophytes (including coccolithophores), some dinoflagellate species, chrysophytes, and centric and pennate diatoms produce the largest amounts of DMS (Keller et al., 1989; Levasseur et al., 1994; Trevena and Jones, 2006). The DMS is emitted at sea ice margins during blooms that follow decay of the sea ice. Because the role of climate in production of DMS and MSA is still uncertain (Abram et al., 2007; Saltzman et al., 1997), we separately compare the flux ratios for the Holocene and for the Last Glacial Maximum. The MSA signal in ice cores is thought to be determined by atmospheric transport strength and to a lesser extent by sea ice conditions (Abram et al., 2007). Antarctica is surrounded by sea ice, on the lower surfaces of which haptophytes live. Greenland is surrounded by far less sea ice than Antarctica. As a consequence of the short residence time in the lower troposphere $(\sim 2.3 \mathrm{~d})$, the MSA concentrations in ice cores likely reflect nearby production and are not very sensitive to MSA emissions from phytoplankton blooms at lower latitudes in the open ocean.

We have reported here our first steps toward a comprehensive record of microbial and non-microbial aerosol fluxes over $>10^{5}$ years in glacial ice. A new version of our fluorimeter has the ability to detect chlorophyll and volcanic ash in addition to protein-bound Trp. In the future we will use the new fluorimeter to enumerate phototrophs, microbial cells, non-microbial aerosols, and grains of volcanic tephra throughout the entire depth of the $\sim 3500$ m WAIS Divide ice core. The data should be sufficiently comprehensive that we can compare time series of microbes and non-Trp aerosols with major ions on a $\mathrm{mm}$ by $\mathrm{mm}$ scale.

Acknowledgements. We thank Nathan Bramall for his contributions to optical design and his measurements of fluorescence spectra of microbial taxa and mineral species. This research was supported in part by NSF Grants ANT-0440609 and ANT-0738658. We thank Eric Craven and others at the US National Ice Core Laboratory for assistance with ice cores.

Edited by: D. Hammarlund

\section{References}

Abram, N. J., Mulvaney, R., Wolff, E. W., and Mudelsee, M.: Ice core records as sea ice proxies: an evaluation from the Weddell Sea region of Antarctica, J. Geophys. Res., 112, D15101, doi:10.1029/2006JD008139, 2007.

Bender, M., Sowers, T., Dickson, M.-L., Orchardo, J., Grootes, P., Mayewski, P. A., and Meese, D. A.: Climate correlations between Greenland and Antarctica during the past 100000 years, Nature, 372, 663-666, 1994.

Bory, A. J. M., Biscaye, P. E., and Grousset, F. E.: Two distinct seasonal Asian source regions for mineral dust deposited in Greenland (NorthGRIP), Geophys. Res. Lett., 30(4), doi:10.1029/2002GL016446, 2003. 
Brook, E. J., Sowers, T., and Orchardo, J.: Rapid variations in atmospheric methane concentration during the past 110000 years, Science, 273, 1087-1091, 1996.

Chappellaz, J., Brook, E., Blunier, T., and Malaizé B.: $\mathrm{CH}_{4}$ and $\delta^{18} \mathrm{O}$ of $\mathrm{O}_{2}$ records from Antarctic and Greenland ice: a clue for stratigraphic disturbance in the bottom part of the Greenland Ice Core Project and the Greenland Ice Sheet Project 2 ice cores, J. Geophys. Res., 102, 26547-26557, 1997.

Coble, P. C.: Characterization of marine and terrestrial DOM in seawater using excitation-emission matrix spectroscopy, Mar. Chem., 51, 325-346, 1996.

Cuffey, K. M. and Clow, G. D.: Temperature, accumulation, and ice sheet elevation in central Greenland through the last deglaciation transition, J. Geophys. Res., 102(C12), 26383-26396, 1997.

De Angelis, M., Steffensen, J. P., Legrand, M., Clausen, H., and Hammer, C.: Primary aerosol (sea salt and soil dust) deposited in Greenland ice during the last climatic cycle: comparison with east Antarctic records, J. Geophys. Res., 102, 26681-26698.

Delmonte, B., Basile-Doelsch, I., Petit, J.-R., Maggi, V., RevelRolland, M., Michard, A., et al.: Comparing the EPICA and Vostok dust records during the last 220,000 years: stratigraphical correlation and provenance in glacial periods, Earth Sci. Rev., 66, 63-87, 2004.

Gilichinsky, D.: Permafrost, in: Encyclopedia of Environmental Microbiology, edited by: Bitton, G., Wiley, New York, USA, 2367-2385, 2002.

Grootes, P. M., Stuiver, M., White, J. W. C., Johnsen, S., and Jouzel, J.: Oxygen variability in Greenland snow and ice with $10^{-3}$ to $10^{5}$-year time resolution, Nature, 366, 552-554, 1993.

Jonsell, U., Hansson, M. E., Siggaard-Anderson, M.-L., and Steffensen, J.-P.: Comparison of northern and central Greenland ice core records of methanesulfonate covering the last glacial period, J. Geophys. Res. 112, D14313, doi:10.1029/2006JD007451, 2007.

Keller, M. D., Bellows, W. K., and Guillard, R. L.: Dimethylsulfide production in marine phytoplankton, in: "Biogenic sulfur in the environment", ACS Symp. Ser., vol. 393, edited by: Saltzman, E. S and Cooper, W. J., Am. Chem. Soc., Washington DC, USA, 167-182, 1989.

Legrand, M., Feniet-Saigne, C., Saltzman, E. S., Germain, C., Barkov, N. I., and Petrov, V. N.: Ice-core record of oceanic emissions of dimethylsulphide during the last climate cycle, Nature, 350, 144-146, 1991.

Legrand, M. R., Hammer, C. U., De Angelis, M., Savarino, J., Delmas, R., Claussen, H. B., et al.: Sulfur-containing species (methanesulfonate and $\mathrm{SO}_{4}$ ) over the last climatic cycle in the Greenland Ice Core Project (central Greenland) ice core, J. Geophys. Res., 102, 26663-26679, 1997.

Levasseur, M., Gosselin, M., and Michaud, S.: A new source of dimethylsulfide (DMS) for the arctic atmosphere: ice diatoms, Mar. Biol., 121, 381-387, 1994.

Li, F., Ginoux, P., and Ramaswamy, V.: Distribution, transport, and deposition of mineral dust in the Southern Ocean and Antarctica: contribution of major sources, J. Geophys. Res., 113, D10207, doi:10.1029/2007JD009190, 2008.

Mayewski, P. A., Meeker, L. D., Twickler, M. S., Whitlow, S., Yang, Q., Lyons, W. B., and Prentice, M.: Major features and forcing of high-latitude northern hemisphere atmospheric circulation using a 110000-year-long glaciochemical series, J. Geophys. Res., 102,
26345-26366, 1997.

Miteva, V. I. and Brenchley, J. E.: Detection and isolation of ultrasmall microorganisms from a 120,000-year-old Greenland glacier ice core, Appl. Environ. Microbiol., 71, 7806-7818, 2005.

Miteva, V. I., Sheridan, P. P., and Brenchley, J. E.: Phylogenetic and physiological diversity of microorganisms isolated from a deep Greenland glacier ice core, Appl. Environ. Microbiol.,70, 202213, 2004.

Miteva, V. I., Sowers, T., and Brenchley J. E.: Geochemical and molecular data support a biogenic origin of methane in the basal Greenland ice, Poster session 3, 24 August 2006, 11th International Symposium on Microbial Ecology, ISME-11, Vienna, Austria, (unpublished).

Mopper, K. and Schultz, C. A.: Fluorescence as a possible tool for studying the nature and water column distribution of DOC components, Mar. Chem., 41, 229-238, 1993.

Pan, Y.-L., Pinnick, R. G., Hill, S. C., Rosen, J. M., and Chang, R. K.: Single-particle laser-induced-fluorescence spectra of biological and other organic-carbon aerosols in the atmosphere: measurements at New Haven, Connecticut, and Las Cruces, New Mexico, J. Geophys. Res., 112, D24S1, doi:10.1029/2007JD008741.

Petit, J. R., Jouzel, J., Raynaud, D., et al.: Climate and atmospheric history of the past 420,000 years from the Vostok ice core, Antarctica, Nature, 399, 429-436, 1999.

Price, P. B.: Microbial life in glacial ice and implications for a cold origin of life, FEMS Microbiol. Ecol., 59, 217-231, 2007.

Priscu, J. C. and Christner, B. C.: Earth's icy biosphere. In Microbial Diversity and Bioprospecting, edited by: Bull, A. T., ASM Press, Washington, DC, USA, 130-145, 2004.

Revel-Rolland, M., De Deckker, P., Delmonte, B., Hesse, P. P., Magee, J. W., Basile-Doelsch, I., et al.: Eastern Australia: a possible source of dust in East Antarctica glacial ice, Earth Plan. Sci. Lett., 249, 1-13, 2006.

Rohde, R. A. and Price, P. B.: Diffusion-controlled metabolism for long-term survival of single isolated microorganisms trapped within ice crystals, Proc. Natl. Acad. Sci. USA, 104, 1659216597, 2007.

Rohde, R. A., Price, P. B., Bay, R. C., and Bramall, N. E.: In-situ microbial metabolism as a cause of gas anomalies in ice, Proc. Natl. Acad. Sci. USA, 105, 8667-8672, 2008.

Röthlisberger, R., Mulvaney, R., Wolff, E. W., Hutterli, M. A., Bigler, M., Sommer, S., and Jouzel, J.: Correction to "Dust and sea salt variability in central East Antarctica (Dome C) over the last 45 kyrs and its implications for southern high-latitude climate", Geophys. Res. Lett., 30, 1216, doi:10.1029/2003GL016936, 2003.

Ruth, U., Wagenbach, D., Steffensen, J. P., and Bigler, M.: Continuous record of microparticle concentration and size distribution in the central Greenland NGRIP ice core during the last glacial period, J. Geophys. Res., 108(D3), 4098, doi:10.029/2002JD002376, 2003.

Ruth, U., Barbante, C., Bigler, M., Delmonte, B., Fischer, H., Gabrielli, P., et al.: Proxies and measurement techniques for mineral dust in Antarctic ice cores, Environ. Sci. Tech., 42, 56755681, 2008.

Saltzman, E. S., Whung, P.-Y., and Mayewski, P. A.: Methanesulfonate in the Greenland Ice Sheet Project 2 ice core. J. Geophys. 
Res. 102, 26649-26657, 1997.

Saltzman, E. S., Dioumaeva, I., and Finley, B. D.: Glacial/interglacial variations in methanesulfonate (MSA) in the Siple Dome ice core West Antarctica. Geophys. Res. Lett., 33, L11811, doi:10.1029/2005GL025629, 2006.

Sowers, T., Alley, R. B., and Jubenville, J.: Ice core records of atmospheric $\mathrm{N}_{2} \mathrm{O}$ covering the last 106000 years. Science 301, 945-948, 2003.

Trevena, A. J. and Jones, G. B.: Dimethylsulfide and dimethylsulphoniopropionate in Antarctic sea ice and their release during sea ice melting, Mar. Chem., 98, 210-222, 2006.

Tung, H. C., Bramall, N. E., and Price, P. B.: Microbial origin of excess methane in glacial ice and implications for life on Mars, Proc. Natl. Acad. Sci. USA, 102, 18292-18296, 2005.
Tung, H. C., Price, P. B., Bramall, N. E., and Vrdoljak, G.: Microorganisms metabolizing on clay grains in 3-km-deep Greenland basal ice, Astrobiology 6, 69-86, 2006.

Wolff, E. W.: The challenge from ice cores: Understanding the climate and atmospheric composition of the late Quaternary, J. Phys. IV France, 139, 185-196, 2006.

Wolff, E. W., Fischer, H., Fundel, F., Ruth, U., Twarloh, B., Littot, G. C., Mulvaney, R., et al.: Southern Ocean sea-ice extent, productivity and iron flux over the past eight glacial cycles, Nature, 440, 491-496, 2006.

Yamashita, Y. and Tanoue, E.: Chemical characterization of protein-like fluorophores in DOM in relation to aromatic amino acids, Mar. Chem., 82, 255-271, 2003. 